\title{
Stock Market Volatility and Macroeconomic Performance in Nigeria
}

Motunrayo Helen Falaye ( $\nabla$ falayemh@abuad.edu.ng )

Afe Babalola University https://orcid.org/0000-0003-2447-7105

Jonathan D. Danladi

ABUAD: Afe Babalola University

Research

Keywords: Stock Market, Volatility, Macroeconomic, Nigeria

Posted Date: August 26th, 2021

DOI: https://doi.org/10.21203/rs.3.rs-816822/v1

License: (c) (i) This work is licensed under a Creative Commons Attribution 4.0 International License. Read Full License 


\section{Abstract}

This study is on the effect of stock market volatility on some selected macroeconomic performance indicators in Nigeria. The first objective was the identification of the determinants of stock market volatility in Nigeria. The second objective was the investigation of the effects of stock market volatility on some selected macroeconomic performance indicators in Nigeria. The third objective was the examination of the causal relationship between stock market volatility and selected macro-economic performance indicators in Nigeria from 1981-2019. The study used secondary data sourced from central bank of Nigeria and World Bank databank.

The variables that turned out to be significant determinants of stock market volatility using the ECM are exchange rate, total savings, consumer price index, foreign direct investment and inflation.

The results from the findings reveal the presence of long run relationship between the variables. This was shown using the Johansen co-integration test which helped to check for long run relationship between the variables. The results further reveal that causality exists between the variables.

This study therefore recommends that the government of Nigeria should make consensus effort towards the revitalization and improvement in the overall efficiency of the significant determinants of stock market volatility in Nigeria, because if this improves the Nigerian stock market it can boost the growth of the overall economy.

\subsection{Introduction}

Stock market is viewed as a medium to encourage savings, help channel savings into productive investment, and improve the efficient and productivity of investment.

An efficient stock market contributes to attract more investment by financing productive projects and lead to economic growth, mobilize domestic savings, allocate capital efficiently, reduce risk by diversifying, and facilitate exchange of goods and services (Mishkin, 2012, Caporale et al, 2014).

Stock market is a critical log in the wheel that smoothens the transfer of funds for economic growth, stock exchange are expected to accelerate economic growth by increasing liquidity of financial assets, making global diversification easier for investors and promoting wiser investment decisions. In principle, a well-functioning stock market may help the economic growth and development process in an economy through growth of savings, efficient allocation of investment resources and all alluring of foreign portfolio investment.

The stock market also encourages savings by providing the household having investable funds, an additional financial instrument which meets their risk preference and liquidity needs better (Agrawalla, 2006) 
Volatility is the statistical measure of the fluctuation of the price or returns of financial markets instruments like stocks and stocks markets indexes. Given two securities, the higher the level of volatility the riskier it becomes. An average investor is assumed to be risk -averse, such that excessive volatility often erodes investors' confidence.

\subsection{Statement of the Problem}

The Nigeria's financial market is relatively shallow and oligopolistic compared with its peers in emerging market economies (National Technical Working Group Report, Vision 20:2020, 2009). Although the financial market has witnessed some expansion in the review period, there are observed problems, which the market has to contend with. From inception the entire performance of the financial market has been mixed. Particularly, been a propeller of sustainable economic growth and development, the financial market in Nigeria has performed below its potential (Nwosu \& Hamman, 2008).

Despite the fundamental functions performed by the Nigerian financial markets (money and capital markets), the key issues facing the Nigerian financial market includes the following: dearth of instruments and lack of market breadth and depth which increases stock market volatility: inadequate skilled manpower resulting in low market development: the oligopolistic structure of the markets: dependence on government resulting in narrow instruments range and slow growth of the secondary market: information gap and asymmetry leading to market inefficiency: inadequate risk management and corporate governance framework: and regulatory challenges. (National Technical Working Group Report; Vision 20:2020, 2009).

More also, one of the greatest challenges facing the Nigeria money market is the establishment of a highly encompassing liquid market in which investors can relatively buy and sell with ease, where larger transactions are carried out without significant changes in prices. This becomes necessary, given the backdrop that well-informed international investors generally consider the level of a market's liquidity before investing in such a market, investors will only look out for a market, which guarantee easy entry and exit. Weak domestic payment systems have also hindered efficient liquidity management and have obstructed the development of the Nigerian financial market. In addition, the absence of efficient and cost effective systems for transferring ownership of the securities traded in the secondary market, or the funds to pay for them has obstructed market development or repurchases transactions.

\subsection{Literature Review}

\subsection{Stocks and Stock Exchanges.}

Financial markets play an important role to allocate funds from surplus units to deficit units. Households, institutions and governments are the major participants in financial markets (Madura, 2001).

When financial market assists the flow of short term funds, funds with maturities of one year or less, then it is known as money market. Whereas financial markets with long term maturities are known as capital 
markets. One of the most common types of capital market securities is stock or equity security (Madura 2001).

Equity securities or stocks represent the ownership of companies. Holding a stock of a company means that the stock holder has the partial ownership of that company and entitles to receive the profit from the company operation.

Stocks comprises of two kinds, the preferred and common stocks. Preferred stocks holders are entitle to a fixed dividend but don't have voting right. Wherefore, stocks or equity securities mostly refers to common stocks. The holder of common stocks has the right of voting and getting dividend. Companies issues stocks to collect long term funds and investors, individual and financial institutions, buy those stocks as a long term investment.

Investors can buy new stocks from primary market existing securities from secondary market. Brokerage firms help investors as a financial intermediary to buy and sell existing stocks in secondary market.

These secondary market transactions can be performed in the over-the-counter (OTC) market if the stocks are not listed on an exchange. Organized exchange is an

established platform for secondary market trading of listed stocks. Transactions in stock exchanges are strictly monitored and regulated by the Securities and Exchange Commission (SEC) and considered safer than OTC transactions (Madura, 2001).

\subsection{EMPERICAL LITERATURE}

Ogboi and Oladipo (2012) in a study titled "Stock market and economic growth: The Nigerian experience", employed the Error Correction Model on an annual time series data from 1981-2008, as well as the Granger Causality Pair-wise Test in order to determine the causal relationship among the variables. Their result indicated that market capitalization (proxy for stock market activities) affects economic growth causally. Thus, an increase in market capitalization will result to availability of more investment funds to the entrepreneurs, thereby leading to economic growth.

Chizea (2012) examined the long-run causal relationship between the stock market and economic growth in Nigeria. The study used one bank and three measures of stock market development: the loans to deposit ratio of banks, market capitalization ratio, value traded to market capitalization ratio as well as value traded to GDP ratio. Employing the Multivariate Vector Autoregressive Models (VAR) and Vector Error Correction Model (VECM) on a time series data (1980-2007), the study revealed that there exist a co-integration between stock market development and economic growth in both short and long-run. Thus, the stock market development has impacted positively on economic growth in Nigeria.

In a more recent study, Onakoya (2013) examined the relative contributions of stock market volatility on economic growth in Nigeria for the periods 1980-2010. Employing Exponential Generalized Autoregressive Conditional Heteroskedasticity (EGARCH), the study revealed that the volatility shock is quite persistent in Nigeria, which might distort economic growth. Thus, the result of the empirical analysis 
suggests that there exist a bi-causal relationship between stock market volatility and economic growth in Nigeria. The result further revealed that small investors are more interested in short-term gains and as such, ignore long-term investment opportunities. Hence, the stock market performance of listed companies in Nigeria can hardly reflect their real economic competence.

Jayasuriya (2002) examines the effect of stock market liberalization on stock return volatility using Nigeria and fourteen other emerging market data, from December 1984 to March 2000 to estimate asymmetric GARCH model. The Nigerian session of the result reveals that returns series exhibited business cycle behaviour than volatility clustering

\subsection{Theoretical Framework And Methodology 3.1 Theoretical Framework}

Theoretically, the Mckinnon and Shaw hypothesis is the foundation in which the model was specified. The theory states that financial liberalization and stock market development would promote economic growth through their effects on the growth rate of savings, investment, and thus economic growth. McKinnon and Shaw (1973) argued that the repressed financial markets (low and administered interest rates, domestic credit controls, high reserve requirements and concessional credit practices) discourages savings, retards the efficient allocation resources, increases the segmentation of financial markets, constrains investment and in term lowers the economic growth rate. The important message of the McKinnon-Shaw hypothesis is that a low or negative real rate of interest discourages savings and hence reduces the availability of loan able funds, constrains investment, and in turn lowers the rate of economic growth.

\subsection{Model Specification}

Macroeconomic variables are interconnected. Change in one variable also affects others and these overall affect the economy of a country. These have effect on the working of equity market. Their linkage is mostly short in nature and get volatile early.

\section{For Objective one: To examine the determinants of stock market volatility in Nigeria.}

In this study, the conditional variances or volatility over time in stock prices is hypothesised to be determined by the macroeconomic variables such as exchange rate, inflation rate, money supply, foreign direct investment, total savings and credit to private sector. Thus, the conditional variance equation is specified as follows in implicit form:

$$
S M V=f(I N F L, F D I, E X R T, M S, T S A V, C P S)
$$

Where;

SMV = stock market volatility as proxied by All share index volatility 
INFL = inflation rate

$\mathrm{FDI}=$ foreign direct investment

EXRT $=$ exchange rate

MS = money supply

TSAV $=$ total savings

CPS $=$ credit to private sector

2. Objective Two: To examine the effects of stock market volatility on selected macro-economic variables performance in Nigeria.

\section{Part A:}

In order to ascertain the effect of stock market volatility on economic growth in Nigeria, the model for this study is specified for the selected macroeconomic variable, GDP:

$$
G D P=f(S M V)
$$

The main independent variable (SMV) was replaced by its proxy (that is, all share index volatility). Other variables are introduced into the model to serve as control variables in the model below. These variables include total savings, money supply, foreign direct investment and exchange rate and the expanded model when logged becomes;

$$
L N G D P=\beta_{0}+\beta_{1} L N A S I+\beta_{2} L N T S A V+\beta_{3} L N M S+\beta_{4} L N F D I+\beta_{5} L N E X R T+\mu
$$

\section{Part B:}

The second part of this analysis will involve domestic investment as the dependent variable. This is the second macroeconomic variable that was chosen. Hence, the effects of stock market volatility on domestic investment will be tested as follows:

$$
D I=f(S M V)
$$

Other variables are introduced into the model to serve as control variables in the model. These variables include total savings, money supply, foreign direct investment and exchange rate and the expanded model when logged becomes

$$
L N D I=\beta_{0}+\beta_{1} L N A S I+\beta_{2} L N T S A V+\beta_{3} L N M S+\beta_{4} L N F D I+\beta_{5} L N E X R T+\mu
$$

Where:

DI = Domestic Investment (Proxy for Gross Capital Formation) 
ASI = NSE all-share index (proxy for stock market volatility);

$\mathrm{FDI}=$ foreign direct investment

EXRT $=$ exchange rate

MS = money supply

TSAV = total savings;

$\mu=$ Error or stochastic term; and

$\beta 1-\beta 3=$ Coefficients.

\section{Objective 3: Testing For The Causal Relationships}

In order to measure the direction of casual relationship among stock market volatility and selected macro-economic performance indicators, the granger causality test will be used to forecast the direction of causation among the variables, to ascertain the variable that granger causes one another.

The implicit function is stated thus;

$$
S M V=f(D I, G D P)
$$

Where SMV = stock Market Volatility

DI = Domestic investment (proxy by gross capital formation)

$\mathrm{GDP}=$ Gross Domestic product

\subsection{Sources of Data}

This study used time series data from 1981-2019 of Nigeria stock index and macroeconomic variables. Stock indices were chosen from Nigeria stock market and data of macroeconomic variables was taken World Bank databank as well as the Central Bank of Nigeria statistical bulletin.

In this study a comprehensive set of macroeconomic variables was used which have a deterministic role for returns in equity market. These variables are real inflation rate, money supply $M_{2}$, foreign direct investment, gross domestic product e.t.c.

\subsection{A priori Expectation}

An a priori expectation is one where certain basic principles are assumed to be true. It is then not necessary to use empirical evidence but rely on the axioms being true. Based on the study done on the impact of stock market volatility on macroeconomic performance in Nigeria: 
$\mathrm{ASI}>0, \mathrm{TSAV}>0, \mathrm{DI}>0, \mathrm{FDI}>0, \mathrm{MS}>0, \mathrm{EXRT}>0, \mathrm{GDP}>0, \mathrm{CPS}>0, \mathrm{INFL}>0$.

All variables are meant to exhibit a positive relationship. The foreign direct investment can yield either a negative or positive relationship depending on the amount of foreign direct investment at the time period.

\subsection{Estimation Techniques}

Unit Root Test, Johansen Co-integration test, Error Correction Mechanism (ECM) and Granger Causality Test were all employed in the analysis of the data.

\subsection{Discussion Of Result}

The tables below confirms that the ADF test results reveal stationary at first difference - All share index volatility (ASIV), Exchange Rate (EXRT), Money Supply (MS), Credit to Private Sector (CPS), Gross Domestic Product (GDP), Domestic Investment (DI), Inflation (INFL), Foreign Direct Investment (FDI) and Total Savings (TSAV). Therefore, this can be also be stated as all the variables used are integrated of order 1 , that is $\mathrm{I}(1)$.

Table 4.1

Stationarity Test Result

\begin{tabular}{|lllll|}
\hline Variables & $\begin{array}{l}\text { Augmented Dickey Fuller Test } \\
\text { Statistic }\end{array}$ & $\begin{array}{l}\text { Probability } \\
\text { Values }\end{array}$ & $\begin{array}{l}\text { Order of } \\
\text { Integration }\end{array}$ & $\begin{array}{l}\text { Maximum Lag } \\
\text { Length }\end{array}$ \\
\hline LNASIV & -8.026875 & 0.0000 & $\mathrm{I}(1)$ & 9 \\
\hline LNEXRT & -5.205054 & 0.0001 & $\mathrm{I}(1)$ & 9 \\
\hline LNMS & -3.357209 & 0.0192 & $\mathrm{I}(1)$ & 9 \\
\hline LNCPS & -4.188023 & 0.0022 & $\mathrm{I}(1)$ & 9 \\
\hline LNGDP & -4.227259 & 0.0020 & $\mathrm{I}(1)$ & 9 \\
\hline LNDI & -3.575208 & 0.0112 & $\mathrm{I}(1)$ & 9 \\
\hline LNINFL & -6.889738 & 0.0000 & $\mathrm{I}(1)$ & 9 \\
\hline LNFDI & -10.22771 & 0.0000 & $\mathrm{I}(1)$ & 9 \\
\hline LNTSAV & -4.490256 & 0.0010 & $\mathrm{I}(1)$ & 9 \\
\hline
\end{tabular}

Source: Author's Computation from EViews 9, 2021.

\subsection{Johansen Co-integration Test: For Objective one: To examine the determinants of stock market volatility in Nigeria}

The results from the co-integration test shows that the variables are co-integrated at $5 \%$ significance level using trace test. This is evident as there exist only one co-integrating equation from the trace test on one hand and no co-integrating equation from the max-eigen value test on the other hand. However, where 
there exists conflicting results, the trace test takes precedence over the max-eigen value test. Hence, it can be concluded that there exists long run relationship between the variables under consideration in the study. 
Table 4.2

(A): Johansen Co-integration Test Result

\section{Hypothesized}

No. of $C E(s)$

None *

At most 1

At most 2

At most 3

At most 4

At most 5

Trace test indicates

1 cointegrating eqn(s) at $5 \%$ significant level

* denotes rejection of the hypothesis at $5 \%$ significant level

**MacKinnon-Haug-Michelis (1999) p-values

Unrestricted Cointegration Rank Test (Maximum Eigenvalue)

Hypothesized

No. of $\mathrm{CE}(\mathrm{s})$

None

At most 1

At most 2

At most 3

At most 4

At most 5

Max-eigenvalue test indicates no cointegration at the 0.05 level

* denotes rejection of the hypothesis at $5 \%$ significant level

**MacKinnon-Haug-Michelis (1999) p-values

Source: Author's Computation from EViews 9, 2021

\section{2(B) Error Correction Model (ECM)}

Statistic

32.96937

27.05327

19.43732

13.37705

10.20154

2.773085
0.05

Critical Value

Prob.**

103.8473

0.0368

76.97277

0.0990

54.07904

0.2219

35.19275

0.3226

20.26184

0.3659

9.164546

0.6239

Max-Eigen $\quad 0.05$

Critical Value

Prob.**

40.95680

0.2972

34.80587

0.3114

28.58808

0.4564

22.29962

0.5203

15.89210

0.3163

9.164546

0.6239

9.164546

0.6239


From the table below, the result shows that the $\mathrm{R}^{2}$ is $76 \%$. This can infer that the independent parameters explain changes in all share indexes. The Adjusted $R^{2}$ is seen to be $61 \%$. This confirms the $R^{2}$. The Probability of the F-statistic is 0.000420 . Since it is less than 0.05 , it can be concluded that the model is significant. The Durbin-Watson stat which explains the co-efficient of serial correlation of the error term shows that the null hypothesis of serial or autocorrelation of the error term should be rejected. The Durbin Watson is seen to be 1.891604 which shows the absence of serial correlation.

The ECM is given as -0.352131 . This shows that the ECM is negative and significant (as seen in the probability value). Thus, we can say that the model is reliable.

Coming down to the variables in the model, the coefficient of inflation (INFL) in the current period is 0.508183 . This means that INFL is positively related to ASIV. This conforms to theoretical expectation which expects it to be positive as an increase in inflation by 1 unit will lead to an increase in all share indexes in the economy by 0.508183 . Thus, it is statistically significant.

The coefficient of foreign direct investment (FDI) in the current lag is 0.293932 . This suggests that FDI is positively related to ASIV and is statistically significant. The theoretical expectation shows that it is positive. This is further explained as a 1 unit increase in FDI will further increase ASIV by 0.293932.

The coefficient of exchange rate (EXRT) in the current lag is 2859.878. This suggests that EXRT is positively related to ASIV and is statistically significant. Hence, a 1 unit increase in exchange rate will boost the economy by 2859.878 .

The coefficient of total savings (TSAV) in current lag is 781070.3. This suggests that TSAV is positively related to ASIV and is statistically significant. Hence, a 1 unit increase in total savings will boost the economy by 781070.3 .

With respect to consumer price index (CPI), it is given as 78.30221 in lag one period. The sign is positive showing a positive relationship between $\mathrm{CPI}$ and ASIV. It means that an increase in consumer price index by 1 unit will stimulate all share indexes by 78.30221 .

Therefore, from the results, it can be seen that the determinants of stock market volatility in Nigeria include exchange rate, total savings, consumer price index, foreign direct investment and inflation. This is because they have been found to be significant. 
Table 4.2

(B): Error Correction Model Test Result

\begin{tabular}{|c|c|c|c|c|}
\hline \multicolumn{5}{|c|}{ Dependent Variable: DASIV } \\
\hline \multicolumn{5}{|c|}{ Method: Least Squares } \\
\hline \multicolumn{5}{|c|}{ Sample (adjusted): 19832019} \\
\hline \multicolumn{5}{|c|}{ Included observations: 37 after adjustments } \\
\hline Variable & Coefficient & Std. Error & t-Statistic & Prob. \\
\hline C & -21006.95 & 30971.34 & -0.678271 & 0.5047 \\
\hline DASIV(-1) & 647466.4 & 8360823. & 0.077441 & 0.9390 \\
\hline DINFL & 0.508183 & 0.146102 & 3.478277 & 0.0019 \\
\hline DINFL(-1) & -1788.548 & 1514.716 & -1.180781 & 0.2503 \\
\hline DFDI & 0.293932 & 0.126006 & 2.332685 & 0.0280 \\
\hline DFDI(-1) & 5.649956 & 4.995736 & 1.130956 & 0.2688 \\
\hline DEXRT & -691.7934 & 1389.328 & -0.497934 & 0.6235 \\
\hline DEXRT $(-1)$ & 2859.878 & 1657.251 & 1.725676 & 0.0984 \\
\hline DMS & -0.110941 & 0.109329 & -1.014745 & 0.3199 \\
\hline DMS(-1) & 0.019772 & 0.066146 & 0.298906 & 0.7675 \\
\hline DTSAV & 781070.3 & 367062.8 & 2.127893 & 0.0448 \\
\hline DTSAV(-1) & 59.73531 & 53.53118 & 1.115898 & 0.2765 \\
\hline DCPS & -34.63037 & 66.70654 & -0.519145 & 0.6088 \\
\hline DCPS(-1) & 78.30221 & 42.15383 & 1.857535 & 0.0767 \\
\hline $\operatorname{ECM}(-1)$ & -0.352131 & 0.155291 & -2.267558 & 0.0335 \\
\hline R-squared & 0.760501 & Mean dep & dent var & 1840.593 \\
\hline Adjusted R-squared & 0.608093 & S.D. deper & lent var & 200647.8 \\
\hline S.E. of regression & 125610.5 & Akaike inf & criterion & 26.61070 \\
\hline Sum squared resid & 3.448973 & Schwarz o & terion & 27.26377 \\
\hline Log likelihood & -477.2979 & Hannan-Q & inn criter. & 26.84093 \\
\hline F-statistic & 4.989894 & Durbin-Wa & son stat & 1.891604 \\
\hline
\end{tabular}




\section{Dependent Variable: DASIV}

Prob(F-statistic) $\quad 0.000420$

Source: Author's Computation from EViews 9, 2021

For Objective Two: To examine the effects of stock market volatility on selected macroeconomic performance indicator (GDP) in Nigeria.

\section{Using Co-integration and Error Correction Mechanism Tests}

The table below reveals results from the co-integration test for the second objective, part (a). The test was done using the trace test as well as the max eigenvalue test. The results reveal that there is long run relationship between the variables. The trace test reveals 4 co-integrating equations while the max -eigen value also reveals no co-integrating equation. Thus, this shows that the variables are co-integrated. 
Table 4.3

(A): Johansen Co-integration Test Result

\section{Hypothesized}

No. of $\mathrm{CE}(\mathrm{s})$

None *

At most 1 *

At most 2 *

At most 3 *

At most 4

Trace test indicates 4 cointegratingeqn(s) at the 0.05 level

* denotes rejection of the hypothesis at $5 \%$ significant level

**MacKinnon-Haug-Michelis (1999) p-values

Unrestricted Cointegration Rank Test (Maximum Eigenvalue)

Hypothesized

No. of $\mathrm{CE}(\mathrm{s})$

None

At most 1

At most 2

At most 3

At most 4

Max-eigenvalue test indicates no cointegration at the 0.05 level

* denotes rejection of the hypothesis at $5 \%$ significant level

**MacKinnon-Haug-Michelis (1999) p-values

Source: Author's Computation from EViews 9, 2021

\section{3(B) Error Correction Model Test Result}

With respect to the overall result from table below, we can see that the $\mathrm{R}^{2}$ is $61 \%$. This can infer that the independent parameters explain changes in gross domestic product (LNGDP). The Adjusted $\mathrm{R}^{2}$ is seen to be $46 \%$. This is believed to confirm the former $\left(R^{2}\right)$. The Probability of the f-statistic is 0.001801 . Since it is less than 0.05 , it can be concluded that the model is significant. The DurbinWatson stat which explains the co-efficient of serial correlation of the error term shows that the null hypothesis of serial or autocorrelation of the error term should be rejected. The Durbin Watson is seen to be 1.946031 which shows the absence of serial correlation. 
The ECM is given as -0.783750 . This shows that the ECM is negative and significant (as seen in the probability value). Thus, we can say that the model is reliable.

With respect to the parameters themselves, we can see that all share index, the major independent parameter (ASIV) in the current lag is given as 67994.71. The sign is positive which corresponds to a priori expectation as an increase in all share index by 1 unit spurs gross domestic investment by 67994.71.

With respect to total savings (TSAV), it is given as 0.502054 in the current lag. The sign is positive showing a positive relationship between total savings and gross domestic product. It corresponds with a priori expectation as an increase in total savings by 1 unit will stimulate gross domestic product by 0.502054. Total savings is insignificant in the first lag though it corresponds with a priori expectation.

With respect to exchange rate (EXRT), it is given as -10.54760 in the current lag and is statistically significant. The sign is negative showing a negative relationship between exchange rate and gross domestic product. In other words, a 1 unit increase in exchange rate will reduce gross domestic product by -10.54760 . Exchange rate is also statistically significant in the second lag. The coefficient is 0.147911 and the sign is positive showing a positive relationship between exchange rate and gross domestic product. In other words, a 1 unit increase in exchange rate will spur gross domestic product by 0.147911 . 
Table 4.3

(B): Error Correction Model Test Result

\begin{tabular}{|c|c|c|c|c|}
\hline \multicolumn{5}{|c|}{ Dependent Variable: DGDP } \\
\hline \multicolumn{5}{|c|}{ Method: Least Squares } \\
\hline \multicolumn{5}{|c|}{ Sample (adjusted): 19832019} \\
\hline \multicolumn{5}{|c|}{ Included observations: 37 after adjustments } \\
\hline Variable & Coefficient & Std. Error & t-Statistic & Prob. \\
\hline C & 0.190945 & 0.176495 & 1.081867 & 0.2896 \\
\hline DGDP(-1) & 0.591809 & 0.199756 & 2.962657 & 0.0064 \\
\hline DASIV & 67994.71 & 35290.39 & 1.926720 & 0.0650 \\
\hline DASIV(-1) & -11605.47 & 37968.88 & -0.305657 & 0.7623 \\
\hline DTSAV & 0.502054 & 0.161544 & 3.107844 & 0.0047 \\
\hline DTSAV(-1) & 2335444. & 7264879. & 0.321470 & 0.7504 \\
\hline DFDI & 4.303577 & 4.860859 & 0.885353 & 0.3841 \\
\hline DFDI(-1) & 1.845732 & 3.735493 & 0.494107 & 0.6254 \\
\hline DEXRT & -10.54760 & 4.731703 & -2.229135 & 0.0359 \\
\hline DEXRT(-1) & 0.147911 & 0.083300 & 1.775636 & 0.0880 \\
\hline $\operatorname{ECM}(-1)$ & -0.783750 & 0.283654 & -2.763053 & 0.0113 \\
\hline R-squared & 0.612350 & \multicolumn{2}{|c|}{ Mean dependent var } & 0.168685 \\
\hline Adjusted R-squared & 0.463253 & \multicolumn{2}{|c|}{ S.D. dependent var } & 0.135039 \\
\hline S.E. of regression & 0.074759 & \multicolumn{2}{|c|}{ Akaike info criterion } & 50.99570 \\
\hline Sum squared resid & 0.128546 & \multicolumn{2}{|c|}{ Schwarz criterion } & 51.47462 \\
\hline Log likelihood & -932.4204 & \multicolumn{2}{|c|}{ Hannan-Quinn criter. } & 51.16454 \\
\hline F-statistic & 4.107075 & \multicolumn{2}{|c|}{ Durbin-Watson stat } & 1.946031 \\
\hline Prob(F-statistic) & 0.001801 & & & \\
\hline \multicolumn{5}{|c|}{ Source: Author's Computation from EViews 9, 2021} \\
\hline
\end{tabular}

Using the Second Macroeconomic Performance Indicator (Domestic investment)

4.4(A) Johansen Co-integration Test Result 
With respect to the results from co-integration, the test was carried out in two ways. The trace test indicates the presence of 3 co-integrating equations. The max-eigenvalue test indicates the presence of no co-integrating equation. Thus, where there are conflicting results between the tests, the trace test prevails. Therefore, we can conclude that the parameters estimated are co-integrated. 
Table 4.4

(A) Error Correction Model Test Result

\section{Hypothesized}

No. of $\mathrm{CE}(\mathrm{s})$

None *

At most 1 *

At most 2 *

0.415349

At most 3

0.260940

0.111937

At most 4

Trace

0.05

Trace test indicates 3 cointegratingegn(s) at the 0.05 level

* denotes rejection of the hypothesis at the 0.05 level

**MacKinnon-Haug-Michelis (1999) p-values

Unrestricted Cointegration Rank Test (Maximum Eigenvalue)

Hypothesized

No. of $\mathrm{CE}(\mathrm{s})$

None

At most 1

At most 2

At most 3

At most 4

Max-eigenvalue test indicates no cointegration at the 0.05 level

* denotes rejection of the hypothesis at the 0.05 level

**MacKinnon-Haug-Michelis (1999) p-values

Source: Author's Computation from EViews 9, 2021

\section{5(B): Error Correction Model Test Result}

The table below shows the results of the error correction model where DI is the dependent variable and second macroeconomic performance indicator.

Looking at the results from the test conducted, the coefficient of all shares index volatility (ASIV) in the lag one period is 0.495704 . This means that ASIV is positively related to DI. This conforms to theoretical expectation which expects it to be positive as an increase in all share index by 1 unit will lead to an increase in domestic investment in the economy by 0.495704 . Thus, it is statistically significant. 
The coefficient of total savings (TSAV) in current lag is 0.487973 . This suggests that TSAV is positively related to DI and is statistically significant. Hence, a 1 unit increase in total savings will boost the economy by 0.487973 .

The coefficient of foreign direct investment (FDI) in the current lag is -502043.6. This suggests that FDI is negatively related to $\mathrm{DI}$ and is statistically significant. The theoretical expectation shows that it is positive. This is further explained as a 1 unit increase in FDI will reduce DI by -502043.6 .

The result from the ECM reveals that it conforms to economic theory as it is statistically significant and negative. The value of the coefficient is given as -2.090698 . This means that the overall model is stable and significant as the ECM is a condition for stability.

The result also reveals the findings from the $R^{2}$, adjusted $R^{2}$, the $p$-value of the F-statistics and the Durbin Watson statistics. The value of the $\mathrm{R}^{2}$ is given as 0.794533 which suggests goodness of fit of the model. It also suggests that the independent variables in the model significantly explain changes in growth of Nigeria as about $79.5 \%$ of changes in the rate of DI of the country is attributed to the independent variables. The Adjusted $R^{2}$ is given as 0.715507 . This further confirms the result of the $R^{2}$. The Fstatistics is given as 2049.425 while the p-value of the F-statistics is given as 0.000001 . This implies that the model is significant and reliable. The value of Durbin Watson is given as 1.965715 showing the absence of autocorrelation in the model. 
Table 4.5

(B): Error Correction Model Test Result

\begin{tabular}{|c|c|c|c|c|}
\hline \multicolumn{5}{|c|}{ Dependent Variable: DDI } \\
\hline \multicolumn{5}{|c|}{ Method: Least Squares } \\
\hline \multicolumn{5}{|c|}{ Sample (adjusted): 19832019} \\
\hline \multicolumn{5}{|c|}{ Included observations: 37 after adjustments } \\
\hline Variable & Coefficient & Std. Error & t-Statistic & Prob. \\
\hline C & -0.163395 & 0.116573 & -1.401652 & 0.1744 \\
\hline DDI(-1) & 1.358516 & 0.228871 & 5.935725 & 0.0000 \\
\hline DASIV & -224318.1 & 1764404. & -0.127135 & 0.8998 \\
\hline DASIV(-1) & 0.495704 & 0.198172 & 2.501385 & 0.0190 \\
\hline DTSAV & 0.487973 & 0.212563 & 2.295663 & 0.0311 \\
\hline DTSAV(-1) & -0.035753 & 0.099928 & -0.357790 & 0.7238 \\
\hline DFDI & -502043.6 & 250376.7 & -2.005153 & 0.0574 \\
\hline DFDI(-1) & 7.988708 & 195.7600 & 0.040809 & 0.9678 \\
\hline DEXRT & -0.039254 & 0.028229 & -1.390562 & 0.1777 \\
\hline $\operatorname{DEXRT}(-1)$ & 0.001495 & 0.020053 & 0.074527 & 0.9412 \\
\hline $\operatorname{ECM}(-1)$ & -2.090698 & 0.650370 & -3.214627 & 0.0051 \\
\hline R-squared & 0.794533 & \multicolumn{2}{|c|}{ Mean dependent var } & 6.440759 \\
\hline Adjusted R-squared & 0.715507 & \multicolumn{2}{|c|}{ S.D. dependent var } & 2.686108 \\
\hline S.E. of regression & 0.096421 & \multicolumn{2}{|c|}{ Akaike info criterion } & -1.552810 \\
\hline Sum squared resid & 0.213830 & \multicolumn{2}{|c|}{ Schwarz criterion } & -0.906394 \\
\hline Log likelihood & 44.50339 & \multicolumn{2}{|c|}{ Hannan-Quinn criter. } & -1.322820 \\
\hline F-statistic & 2049.425 & \multicolumn{2}{|c|}{ Durbin-Watson stat } & 1.965715 \\
\hline Prob(F-statistic) & 0.000001 & & & \\
\hline
\end{tabular}

\subsection{Granger Causality Result}

Objective Three: Testing For the Causal Relationships 
From the table below, it can be seen that causality runs only one way. This means uni-directional causality exists between the variables under study (that is, ASIV, DI and GDP). This is obvious as when domestic investment granger causes all share index, all share index does not granger cause domestic investment. Also, the table reveals that gross domestic product granger causes all share index but this is not the same as all share index does not granger caused gross domestic product. Similarly, gross domestic product does not granger caused domestic investment, domestic product granger causes gross domestic product.

Table 4.6

Granger Causality Result

\begin{tabular}{|lccc|}
\hline \multicolumn{4}{|l|}{ Pairwise Granger Causality Tests } \\
\hline Sample: 19812019 & & & \\
\hline Lags: 2 & Obs & F-Statistic & Prob. \\
\hline Null Hypothesis: & 37 & 4.24825 & 0.0231 \\
\hline LNDI does not Granger Cause LNASIV & & 0.36069 & 0.7000 \\
\hline LNASIV does not Granger Cause LNDI & & 5.19534 & 0.0111 \\
\hline LNGDP does not Granger Cause LNASIV & 37 & & \\
\hline LNASIV does not Granger Cause LNGDP & & 0.49608 & 0.6135 \\
\hline LNGDP does not Granger Cause LNDI & 37 & 1.34520 & 0.2748 \\
\hline LNDI does not Granger Cause LNGDP & 8.40076 & 0.0012 \\
\hline Source: Author's Computation from EViews 9, 2021 & \\
\hline
\end{tabular}

\subsection{Conclusion And Policy Recommendation 5.1 Conclusion}

The stock market degree of capitalization has always been used as a benchmark to evaluate the performance of the Nigerian stock market towards economic growth. It is a major performance indicator used in determining the worth of the market and a parameter that cannot be ignored by operators and dealers in capital market.

The demand for the services of the stock market is a derived demand, hence, there should be sustained effort to stimulate productivity in both the public and private sectors. The government through its respective specialty units should boost savings and investors' confidence by putting in place policies which give equal importance to both bank-based financial sector as well as the market-based stock economy in order to enhance capital formation, encourage private sector to invest in capital market. 
The increasing importance of financial markets has reinforced the need to study the impact of stock market volatility on some macroeconomic performance indicators in Nigeria.It is therefore pertinent to note that many determinants other than those mentioned in this study influence the development of stock market in an economy, but it would be difficult to capture all these determinants in our model so only few of them were used.

\subsection{Policy Recommendations}

In all stages of economic growth in Nigeria, great reliance has been placed on the stock market as the medium of interaction which facilitates the exchange of the long-term funds within the nation's economic units to achieve an optimal financial flow so as to optimize investment and growth. For the stock market to achieve this objective, it is recommended that:

Firstly, the governments of the Nigeria nation should empower their agencies, ministries and departments to effectively collect and analyse data. Proper data is the bedrock of every research. Use of accurate data, will produce more reliable.

The result from the analysis shows that the all shares index is one of the best proxies for stock market volatility in Nigeria. The efficiency of this parameter ought to be a point of interest to the government; therefore, this study recommends that the governments should make consensus effort towards the revitalization and improvement in the overall efficiency of the significant determinants, because if this improves the Nigerian stock market it can boost the growth of the overall economy. Moreover, there is a need to invigorate and strengthen the financial market; more companies should be encouraged to get listed on the floor of the market. Small and medium entrepreneurs should be allowed to access the market for investible funds given their close affinity with the grass root funds mobilization ability.

The government should make sure that conscious efforts should be made to make sure that financial institutions are in order because they are the ones that control the rate of interest in the economy and these interest rates can influence the level of investment in the economy. A stable interest rate is necessary for attracting FDI, and all these lead to stock market volatility.

The government should also put in measures to ensure that the output of the nation is on the increase, as this not only improves the stock market but also determines overall growth in the economy.

\section{Declarations}

ETHICS APPROVAL AND CONSENT TO PARTICIPATE: Not applicable

CONSENT FOR PUBLICATION: Not application

\section{AVAILABILITY OF DATA AND MATERIAL:}

Dataset used and/or analysed during the current study are available on World Bank databank. 
COMPETING INTERESTS: Authors declared that they have no competing interest.

\section{FUNDING:}

Authors' are responsible for the funding of all the research processes, while Afe Babalola University , AdoEkiti (ABUAD) will be responsible for the payment of the publication fee.

\section{AUTHORS' CONTRIBUTIONS}

Danladi D. Jonathan- He analysed the dataset on stock market volatility and macroeconomic variables.

Falaye M. Helen- She interpreted the analysed data and she gathered the literature used for the study.

The two authors' read and approved the final manuscript

ACKNOWLEDGEMENTS: Not applicable

AUTHORS' INFORMATION: Not applicable

\section{References}

Agrawalla R.K, Wu G (2006) Stock market manipulation-theory and evidence. In: Paper presented at the AFA 2004 San Diego Meetings. Accessed 24 Nov 2016

Chizea, J. (2012). Stock market development and economic growth in Nigeria: A time series study for the period 1980-2007. Doctoral thesis, Nurthumbria University. Retrieved from http://nri.northumbria.ac.uk/10337/.

Gujarati D.N. (1995) Basic Econometrics, 3rd edn. McGraw-Hill, New York. ISBN 0-07-

025214-9

Jayasuriya, S. (2002). Does Stock Market Libralisation Affect the Volatility of Stock

Returns? Evidence from Emerging Market Economies. Georgetown University Discussion Series.

McKinnon, R. I. (1973). Money and Capital in Economic Development; Washington

D.C. The Bookings institution.

Mishkin, F. (2012), “What Depressed the Consumer? The Household Balance Sheet and the

1973-1975 Recession”, Brookings Papers on Economic Activity, Vol. 1, pp. 123-164.

Madura, Jeff, (2001). Financial markets and institutions. 5th edition. Ohio: South Western 
college publishing. Mathematical Finance, 4, 183-204.

Nwosu, C. P. \& Hamman, H. M. (2008). The Nigerian Money Market: Issues and Challenges. Bullion, Publication of the Central Bank of Nigeria, 32(1)

Ogboi, C., \& Oladipo, S.O. (2012). Stock market and economic growth: The Nigerian experience. Research Journal of Finance and Accounting, 3 (4), 103-110.

Onakoya, A. B. (2013). Stock market volatility and economic growth in Nigeria (1980-2010). International Review of Management and Business Research, 2 (1), 201-209.

Ogboi, C., \& Oladipo, S. O. (2012). Stock Market and Economic Growth: The Nigerian Experience. Research Journal of Finance and Accounting, 3 (4), 103-110.

Technical committee, IOSCO (2009). Indexation: Securities Indices and Index Derivatives. 